\title{
O Município na Colômbia
}

ANTÔNIO C. CORTÉs

I

ORIGENS HISTÓRICAS DO MUNICÍPIO COLOMBIANO. EvOluÇÃó LEGAL E REgime ATUAL. SUa ADMINistração.

A NTES de entrar na matéria, parece necessário dar uma síntese da organização geral do país.

A Colômbia é uma república unitária que tem aproximadamente .... $1.200 .000 \mathrm{~km} 2$ e uma população de 13.000 .000 de habitantes. Do ponto de vista administrativo, está dividida em Departamentos, Intendências e Comissarias (segundo o grau de desenvolvimento econômico e social alcançado pelas diferentes regiões) que se subdividem em municípios e êstes por sua vez em "corregimentos". Atualmente existem cêrca de 820 municípios em todo o país.

A Constituição nacional estabelece a tripartição clássica do poder, reconhecendo a autonomia de cada ramo.

O Poder Executivo é exercido pelo Presidente da República, eleito, popularmente, por um período de quatro anos, e pelos Ministros de sua livre nomeação (Govêrno, Educação, Relações Exteriores, Fazenda, Trabalho, Indústria e Comércio, Agricultura e Pecuária, Guerra, Minas e Petróleo, Higiene, Comunicações, Justiça e Obras Públicas).

O Ministro do Govêrno nomeia os governadores, intendentes e comissários êstes os alcaides, e os alcaides, os "corregedores".

O Poder Legislativo é exercido, nacionalmente, pela Câmara dos Deputados e pelo Senado, eleitos, popularmente; os membros da primeira por períodos de dois anos e os do segundo por quatro.

Nos Departamentos, pelas assembléias departamentais, cujos membros são eieitos pelo povo, por um período de dois anos, e nos Municípios, pelo Conselho ou Câmara Municipal, também eleitos pelo povo por dois anos.

O Poder Judiciário tem quatro jurisdições principais: a civil, a penal, a do trabalho e a contenciosa-administrativa. As duas primeiras têm a seguinte hierarquia comum: Côrte Suprema de Justiça, Tribunais Secionais, Juízes de Circuito (conjunto de vários Municípios) e Juízes Municipais.

Os magistrados da Côrte Suprema são eleitos por períodos de cinco anos pelo Parlamento Nacional (Câmara e Senado), e seus nomes são tirados de 
listas de candidatos apresentadas pelo Presidente da República, à razão de três nomes para cada magistratura. Cada Câmara elege um metade, e quando o número é ímpar, a dos deputados elege mais um. A Côrte nomeia cs magistrados dos Tribunais Secionais por um período de quatro anos, e êstes, os Juízes de Circuitos e Municipais, pelo espaço de dois anos.

A jurisdiçấo do trabalho é exercida por um Tribunal Supremo, por Tribunais Secionais e por juízes locais. O Tribunal Supremo é eleito pela Câmara dos Deputados, figurando os candidatos em listas apresentadas pela Presidência da República nas mesmas condições da Côrte Suprema. O Tribunal nomeia os membros dos tribunais Secionais e êstes, os juízes locais.

A jurisdição contencioso-administrativa é exercida pelo Conselho de Estado (eleito pelo Parlamento da mesma forma que a Côrte Suprema), o quai nomeia os membros dos Tribunais Secionais. A esta jurisdição corresponde o contrôle dos atos administrativos nacionais, departamentais e municipais.

Existem outras jurisdições de âmbito mais reduzido tais como o aduaneira, a militar, a de menores. Na eleição e nomeação dêste pessoal guarda-se a proporcionalidade dos partidos políticos (Conservador e Liberal) em que se divide a opinião pública nacional.

Esta organização é a consagrada pela Constituição e pełs leis da República. Atualmente, no entanto, por causa do estado de sítio decretado para o páís e em virtude da subversão institucional causada pela queda do Presidente constitucional, em 13 de junho de 1953, a organização e a vida democrática do país vêm passando por modificações substanciais.

Apresentada esta síntese, entremos no assunto que nos preocupa.

\section{I - ORIGENS HISTÓRICAS DO MUNICÍPIO COLOMBIANO}

As instituições jurídicas do Reino de Castela foram transplantadas, com ligeiras modificações, às novas terras descobertas por CoLombo e conquistadas e colonizadas pelos espanhóis. Entre essas instituições estava, em primeiro lugar, o Município, que ao implantar-se na América adquiriu vitalidade e vigor surpreendentes. As novas características econômico-sociais do ambiente influiram favoràvelmente na instituição municipal. Os conselhos das novas cidades coloniais ofereceram outros campos aos privilégios da nobreza, integrada pelos descendentes dos primeiros descobridores, e aos abusos de poder da incipiente burocracia.

A legislação das Índias atendia, cuidadosamente, não só à aplicação institucional do Município castelhano nas colônias, mas também às condições e requisitos mais diversos que se deviam cumprir na fundação de cidade e vilas.

Sôbre êste ponto é notável a Ordenação n. ${ }^{\circ} 11$, de 1523 , expedida pelo Imperador CARLOS V, que dispõe, entre outras coisas, sôbre os requisitos que so deveriam observar na fundação de cidades: as marítimas teriam que dispor áe pôrto abrigado, provido de ancoradouro e definido, e as mediterrâneas teriam que ser de fácil acesso, e estar localizadas em lugar salubre o propício ao abastecimento de águas, materiais de construção e gêneros alimentícios. O traçado das cidades devia fazer-se por praças, ruas e pátios, a "cordel e régua", começando pela praça maior e dela fazendo sair as ruas, deixando-se 
tanto compasso aberto que, mesmo no caso de a população aumentar consideràvelmente, se pudesse ampliar sua área. Estas normas, no que respeita a Colômbia, foram geralmente seguidas, como o demonstram os excelentes portos de Santamarta, Cartagena e Buenaventura, e a monótona semelhança do traçado das cidades e povoações do interior.

A regulamentação dos Concelhos era minuciosa e severa. Os seus membros deviam ser residentes na localidade, sendo, por isso, na sua maicr parte, nativos. O número de Concelheiros variava, segundo a importância das cidades. A sua escolha era feita por eleição direta ou por sorteio e, em determinadas ocasiões, eram nomeados pela Coroa.

A eleiçãc do Alcaide (Prefeito) realizava-se de acôrdo com a Real Ordenação, de 6 de novembro de 1528, que dispunha "que para a eleiçâo de alcaides ordinárias, se nomeiem cinco pessoas designadas, duas pelo Concelho, uma pelo Governador ou pelo seu lugar-tenente, e outras duas pelos regedores, e se ponham os seus nomes numa urna e os dois primeiros que sairem o sejam". Contudo, havia cidades com autonomia para eleger os seus alcaides.

Nas povoaçöes inteiramente indigenas, o alcaide devia ser índio da mesma localidade, segundo a Lei 15 , da Recompilaçảo das Índias

Aos alcaides competia, entre outrés coisas, a manutenção da ordem pública, a presidência do Conc lho, a defesa da fazenda comum, o contrôle e direçâo das obras públicas.

A autonomia municipal era completa, constituindo "uma fôrça livre, igualmente apta para o bem e para o mal". Os Concelhos secundavam algumas vézes e outras estorvavam as disposiçōes das autoridades supsriores. H storiadores de reconhecida autcridade admitem que a organizaçăo municipal espanhola foi uma das mais notáveis e excelentes obras da metrópole nas culônias.

Assim, por exemplo, disse ALBERDI : "Antes da instauração da República, a soberania do povo existia na América do Sul, como fєto e como princípio, no sistema municipal que nos havia dado a Espanha. A política e a administração estavam separadas: a política pertencia ao Govêrno; a administração ao porvo, diretamente".

As palavras transcritas têm aplicaçāo integral no caso particular da Colómbia.

\section{Evolução legal e regime atual}

O regime municipal, existente à época da proclamação da independência subsistiu por longos anos, pois os novos legisladores sentiam-se absorvides, no afã de estruturar o Estado nos seus aspectos de conjunto, conservando, por isso, a crganização interna existente, uma vez que nâo se opunha acs ideais do movimento emancipador.

Na Colômbia, as diversas constituições nacionais no século passado mantiveram, mais ou menos, a estrutura municipal da colônia. Durante o período em que o país se organizou como Repúblice Federal, alguns Estados regulamentaram as funções do Concelhos ou Câmaras Municipais de forma minuciosa. Assim, por exemplo, a Constituição de Cartagena proibia os cargos de Conselheiros perpétuos, vendáveis e renunciáveis, tornanda-os, pelo contrário, 
um dever e uma honra com que se devia distinguir aos cidadãos mais honrados. E a de Antióquia atribuia-lhes funções como estas: "examinar, propor e executar os projetos e medidas úteis ao público; a proporção, segurança e beleza dos edifícios; a distribuição das águas; o consêrto e abertura de ruas e caminhos; a comodidade e honesta recreação dos habitantes e tudo quanta conduzisse ao ornamento, à formosura, à salubridade e à limpeza das cidades; o asseio, desafôgo e até comodidade nas cadeias; o abastecimento da população, a abundância, boa qualidade e barateza dos alimentos, sem onerar artigo com qualquer impôsto".

A Constituição de 1886 que, com ligeiras modificações, é a mesma que vigora atualmente, consagrou o Município como entidade meramente administrativa, atribuindo as Câmaras Municipais: "ordenar o conveniente para a administração do distrito, impor contribuições e decretar as despesas públicas locais; registrar o movimento anual da povoação e as demais funções que as leis determinem".

Pela primeira vez, em 1888, a Lei N..$^{\circ} 149$ consolidou tôda a legislação municipal um corpo único que se denominou "Código Político e Municipal".

Êste código vigorcu até 1913 quando foi substituído pela Lei $4 .^{a}$ do mesmo ano, que consubstanciou normas mais de acòrdo com a evolução social, política e econômica do país .

As disposições desta lei, apesar de alteradas por diversas leis posteriores, são as que regem hoje o Municipio colombiano, não levando em conta os decretos expedidos sôbre a matéria pelo atual govêrno e durante o estado de sitio.

\section{A Administração}

A Lei 4. a ; de 1913, acima citada, dedica ao Município oito capítulos que tratam respectivamente de: Disposições Gerais (ou princípios e conceitos fundamentais sôbre a administração); Municipios e Corregimentos; Concelhos; Atribuições dos Concelhos; Acôrdos; Anulação dos Acôtdos; Alcaides e Corregimentos e Bens. Impostos e Gastos dos Municípios.

Examinar-se-ão, em seguida, os sete primeiros capítulos do Código men. cionado, deixando-se o último para a segunda parte dêste estudo.

\section{Como se cria um Município na Colômbia}

Para a criação de um Município, a Lei exige requisitos de caráter demográfico, econômicc e territorial.

Quanto ao primeiro, a região pretendente à condição de Município deve ter, pelo menos, 10.000 habitantes, e o que sofre desmembramento precisa ficar com pelo menos 15.000; deve possuir uma povoação onde residam no mínimo 150 famílias e um número suficiente de pessoas, aptas ao desempenho das funções administrativas; cumpre ainda que a criação do novo município seja solicitada pela metade dos cidadãos, em pleno uso de direitos políticos.

Quanto aos requisitos econômicos exigem-se: (1) que nos últimos três anos a localidade tenha contribuído para os cofres do município ou municípios dos quais se quer segregar, com uma soma não inferior a 6.000 ; (2) que esteja em condições de organizar as suas rendas com um orçamento não inferior 
a 14.000 pesos anuais, e (3) que a localidade que pretende ser sede do município disponha de edifícios para o funcionamento dos serviços.

Quanto ao último requisito exige-se que cada município ou municípios dos quais se segrega a nova unidade conservam duas têrças partes do seu território.

Sempre que sejam satisfeitos êstes requisitos, a Assembléia departamental pode decretar a Constituição do novo município.

\section{Aǵregação e Segregaação de Têrmos Municipais}

Para a agregação e segregação de têrmos municipais, circunstâncias que só são possiveis entre os municipios do mesmo Departamento, Intendência ou comissaria, a assembléia respectiva pode deliberar por solicitação justificada, feita pelos Concelhos interessados e pela metade, pelo menos, dos cidadãos da região que se trata de desmembrar. Os municípios que sofrem a segregação devem ficar com os requisitos exigidos para a criação de municípios.

\section{Supressão de Municípios}

As assembléias departamentais podem eliminar os municípios cuja população seja menor de que 3.000 habitantes e cujas rendas, nos dois anos imediatamente anteriores, sejam inferiores à metade do valor dos gastos forçados da sua administração.

\section{"Corregimentos"}

Quando num município existem povoações importantes nas quais convém estabelecer uma administração especial, a lei permitı aos Concelhos dar-lhes a categoria de "Corregimentos" a cargo de "Corregedores" nomeados pelo alcaide.

\section{Classe de Municipios}

A Constituição permite que a lei estabeleça diversas categorias de Municípios, de acôrdo com a sua população, recursos fiscais e importância econômica, e assinalar-lhe diferentes regimes para a sua administração. Mas até agora nenhuma lei fêz uso dessa taculdade.

No entanto, existem leis que, sem estabelecer expressamente categorias de Municípios, permitem a alguns de grande desenvolvimento econômico, organizar a sua administração e o respectivo contrôle de maneira mais ampla do que a lei comum estabelece. Assim, êstes Municípios podem organizar diversas secretarias, fiscalização especial, etc.

Bogotá, a Capital da República, desde há três anos, tem um estatuto de exceção que a consagra "Distrito Especial".

\section{O Govêrno Municipal}

O Govêrno Municipal da Colônia está a cargo do Concelho, de um Procurador, de um Alcaide (Prefeito) e seu secretário e de um Tesoureiro. Em alguns Municípios existe um Fiscal de Contas. 


\section{O Concelho}

Como já vimos, o Concelho é o órgão legislativo do Município. E' de eleição popular por um período de dois anos e compõe-se de cinco (5) membros nos Municípios que têm população inferior a 5.000 habitantes; de sete (7), nos de 5.000 a 10.000 ; de nove (9) nos de 10 a 20.000 ; de onze (11) nos de 20 a 50.000 e de quinze (15) nos de população superior a 50.000 habitantes.

O cargo de concelheiro é gratuito, obrigatório e renunciável só por causa justificada.

Segundo a lei essa corporação é de caráter essencialmente administrativo e nâo político. Contudo, na sua formação respeita-se a proporcionalidade dos partidos políticos (Conservador e Liberal) e, ccm freqüência, na sua atuação intervêm e prevalecem interêsses partidários.

Os atos do concelho denominam-se Acuerdos Municipales, através dos quais se ordena tôda a administração local e se decretam os impostos e as despesas do município.

\section{O Procitrador}

O Concelho Municipal elege por períodos anuais o Procurador Municipal que é representante legal do Município e do próprio Concelho. As suas funções são múltiplas, pois vão desde a vigilância sôbre o cumprimento de disposições locais e sôbre a defesa dos interêsses comuns, até a aplicação das leis departamentais e nacionais no Município, e a fiscalização dos funcionários em tôda a hierarquia, inclusive as decisôes dns juízes çm jurisdiçăo local.

\section{O Alcaide}

O Governador do Departamento nomeia o Alcaide pelo período de um ano, tornando-se seu representante legal. E o administrador local e executor dos acôrdos do Concelho, com poderes de regulamentação. O ordenado do Alcaide é fixado pelo Governador, mas pago pela Fazenda Municipal. O Alcaide, além das suas funções administrativas, é, também, funcionário da instrução dos processos penais.

\section{O Tesoureiro}

O tesoureiro do Municípios é eleito pelo Concelho, anualmente c para garantir a sua gestão deve dar caução prévia. Goza de jurisdição coativa na cébrança dos impostos.

\section{Contrôle Financeiro}

Nos Municípios comuns, o contrôle fiscal é exercido pela Contadoria Departamento, diretamente. Nas capitais de Departamento e cidedes principais, o Concelho nomeia um contador (controlador) gue examina, em primeira instância, as contas, e em seguida, a Contadoria Departamental. 


\section{Estatuto do Funcionário Municipal}

Não existe no país um corpo de disposições legais que tenha o nome de Estatuto do Funcionário Público, e menos ainda, do Funcionário Municipal. As dispcisições dispersas que consagram alguns dos seus direitos tampouco merecem, no seu conjunto, tal título.

A nomeação do empregado municipal é feita pelo período de um ano, mas ao mesmo tempo a lei consagra a favor de quem o nomeia a faculdade de o substituir dentro dêsse prazo, com inteira liberdade.

O funcionário municipal, como qualquer outro do país, goza dos seguintes benefícios: férias remuneradas de 15 dias úteis por ano de serviço; auxílio por doença, equivalente a duas têrças partes do ordenado mensal, curante os primeiros seis meses; auxílio-dispensa, concedido quando o empregado é despedido à razão de um mês de vencimentos por cada ano de trabatho e seguro de vida equivalente ao valor do vencimento anual.

Fora dêsses benefícios obrigatórios, cada Município pode estabelecer outrcs a favor dos seus funcionários.

\section{Situação Jurídica atual do País}

O estado de sítio, decretado pelo govêrno, não permite o funcionamento do Congresso, das Assembléias departamentais e dos Concelhos, na forma previste. pela Constituição.

Em lugar do Congresso Nacional, existe uma corpcração denominada Assembléia Nacional Constituinte; em lugar das Assembléias funcionam os chamados Concelhos Administrativos Departamentais e em lugar do Concelho funciona um Concelho Administrativo Municipal. Nenhuma destas corporações é constituída por eleição popular. 